\title{
RELATIONSHIP BETWEEN THE BRENT OIL PRICE AND THE US DOLLAR EXCHANGE RATE*
}

\section{Radmila Krkoškováa}

\begin{abstract}
This article deals with an analysis of the relationship between the Brent oil price and the US dollar price. This paper analyses the development of the intensity and direction of dependence between the nominal effective exchange rate of the US dollar and the price of Brent oil and other commodities, such as industrial metals, agricultural commodities, gold (including jewellery and platinum) in the period from January 1994 to April 2018. The next section tests the hypothesis that there is a short-term relationship between the effective US dollar exchange rate and the oil price. The last part of the article deals with the question whether there is a long-term relationship between these variables: Brent oil price, effective exchange rate of the US dollar, industrial production index in OECD countries, three-month treasury bill, US ending stocks of crude oil, US percent utilization of refinery operable capacity and the price of ethanol.
\end{abstract}

Keywords: ADF test, Brent, Granger causality, Johansen test, US dollar, VECM JEL Classification: C13, C19, C49

\section{Introduction}

The dependence between the development of the oil price and the US dollar exchange rate, which has been observable since the 1990s, attracts the interest of many economists. The fact that commodity prices are predominantly expressed in US dollars naturally raises the question of the relationship between their prices and the development of the dollar exchange rate. Commodities are traded in one currency for reasons of transparency, costs and risk.

a Silesian University in Opava,School of Business Administration in Karviná, Karviná, Czech Republic

Email: krkoskova@opf.slu.cz

* This paper was supported by the Ministry of Education, Youth and Sports Czech Republic within the Institutional Support for Long-term Development of a Research Organization in 2018. 
The increasing contradictory relationship between the Brent oil price traded in US dollars and the US dollar exchange rate is clearly evident, especially since 2002, when the steadily rising oil price was accompanied by a weakening of the US dollar. This development culminated in 2008 when the US dollar exchange rate was weakened to its historical low in March, and the average monthly Brent oil price reached its historic maximum of 134 USD per barrel in June 2008.

The correlation coefficient reached the average value of $k=-0.6$ in 2007-2011. A similar contrary relationship with the US dollar exchange rate was also observed for other commodities such as industrial metals or agricultural commodities. One explanation for this inverse relationship is the growing role of investors on commodity markets, connected with declining financial asset yields (low interest rates) in developed countries. On average, three-month money market rates on the US dollar have reached only $2 \%$ since 2002 , compared with an average of $6 \%$ between 1982 and 2001, as reported in the CNB report (CNB, 2011).

Oil prices are dropping today, mainly due to the increasing US dollar exchange rate. The Brent oil price was 66 USD per barrel in April 2018. The US Government's Energy Information Administration (EIA) states that oil reserves in the US declined over the period, as set out in W4T (2018).

\section{Theoretical Background}

There are basically two approaches in the literature that explore the relationship between oil prices and exchange rates. The first approach explores the real effective exchange rates of specific countries and uses the real oil price, as stated by Amano and van Norden (1998), Chaudhuri and Daniel (1998), Bénassy-Quéré et al. (2005), or Habib and Kalamova (2007). The result of this approach is, in most cases, the finding of a strong dependence between the two variables, where the real oil price acts on the real effective exchange rates of the respective countries. Oil is involved in the total imports of most industrialized countries, so this conclusion is in line with economic theory.

This article deals with the second approach, which examines the relationship between the development of oil price and the exchange rate in which the oil is traded, that is, the US dollar. According to Muñoz and Dickey (2009), US dollar fluctuations affect commodity prices in US dollars. The results of this approach confirm the contrary effect of both quantities, namely that a weakening US dollar causes an increase in the price of oil and other commodities and, on the contrary, a strengthening US dollar causes a decline in oil and commodity prices, as reported by Cuaresma and Breitenfellner (2008), Brown et al. (2008), Schulmeister (2009), Hošek et al. (2011). 
Basher et al. (2012) study the dynamic relationship between oil prices, exchange rates and emerging market stock prices. A structural vector autoregression model is proposed and estimated and positive shocks to oil prices tend to depress emerging market stock prices and US dollar exchange rates in the short run.

Chen et al. (2016) investigate the impacts of oil price shocks on the bilateral exchange rates of the US dollar against currencies in 16 OECD countries. Their empirical findings indicate that the responses of dollar exchange rates to oil price shocks differ greatly depending on whether changes in oil prices are driven by supply or aggregate demand. Oil shocks can explain about $20 \%$ of exchange rate variations and the relationships between oil and exchange rates are not nonlinear.

Beckmann and Czudaj (2013) take into account two previously neglected issues in their analysis of the relationship between oil prices and effective dollar exchange rates, namely, nonlinear adjustment dynamics and a distinction between nominal and real linkages. Their findings show not only that the results depend on the choice of the exchange rate measure, but also that the time-varying causality patterns mainly run from nominal exchange rates to nominal oil prices.

Aloui et al. (2013) study the conditional dependence structure between crude oil prices and US dollar exchange rates in the period 2000-2011 using a copula-GARCH approach. The rise in the price of oil is found to be associated with the depreciation of the dollar.

Chang et al. (2013) examine the correlations of oil prices, gold prices and the NT dollar versus US dollar exchange rate. No co-integration relationships are found among oil, gold and exchange rate markets. The VAR model found that the gold price was independent, while the oil prices ranked second.

Jawadi et al. (2016) study the dynamics of oil price volatility using intraday data. They find a negative relationship between the dollar/euro exchange rate and oil returns. The authors show that a volatility spillover from the USD/EUR exchange rate to the oil price occurs through jumps.

Yang et al. (2018) obtain long-term correlations between oil prices and exchange rates by employing a dynamic conditional correlation-mixed data sampling (DCC-MIDAS) model. They find that the long-run correlations between oil prices and exchange rates are negative for all oil-exchange rate markets except Japan. The empirical results show that an increase in inflation will significantly damage the real value of the currency itself.

Berument et al. (2014) declare that: oil prices in USD and exchange rate changes affect petroleum prices differently; oil prices increase petroleum prices more than exchange rate in the long run; and oil prices increase petroleum prices less than exchange rate in the short run.

Novotný (2012) states that, growth in the intensity of the inverse relationship between the US dollar exchange rate and the Brent crude oil price has been observed over the last 
decade. This analysis examines monthly data from January 1982 to September 2010. Since 2002, the direction of the relationship in the Granger causality sense has been from the dollar exchange rate to the oil price. Stoklasová (2018b) states that there is a long-term relationship between gold prices and oil prices. This analysis examines monthly data from April 1983 to December 2016.

Kiran (2011) examines the long-run relationship between oil prices and stock market prices of $\mathrm{G} 7$ countries by using Robinson tests for fractional integration and cointegration instead of the conventional approaches. Having found that the unit root null hypothesis cannot be rejected for any individual series, it is examined whether oil prices and stock market prices have a fractional cointegration relationship.

Important is the biofuel part of the crude oil-commodities circle. Filip et al. (2016) present a combination of minimum spanning tree correlation filtration and wavelet analysis, uncovering the ties in a wide portfolio of 33 commodities and relevant assets for biofuels between 2003 and 2016. The authors show that for Brazilian and US ethanol, their respective feedstock leads biofuel prices, and not vice versa.

Kristoufek et al. (2014) find that both ethanol and biodiesel prices are responsive to their production factors (ethanol to corn, and biodiesel to German diesel). Kristoufek et al. (2016) show that the long-run relationship between prices of ethanol and corn (in the USA) or sugar (in Brazil) is positive, strong and stable in time. Importantly, they show that the prices of feedstock lead the prices of ethanol and not the other way around. The price lead of feedstock is documented for both short and long-run horizons.

The article by Serra and Zilberman (2013) concludes that energy prices drive longrun agricultural price levels and that instability on energy markets is transferred to food markets. The results of Serra et al. (2011) indicate the existence of long-run relationships among the ethanol, corn, oil, and gasoline prices analysed. Strong links between energy and food prices are identified.

\section{Data and Methods}

Monthly data for the period from January 1994 to April 2018 were used for the calculations. EViews software version 9 was used for the calculations. The Federal Reserve Bank of St. Louis (FRED), Energy Information Administration (EIA), International Monetary Fund (IMF), Organisation for Economic Co-operation and Development (OECD) and United States Department of Agriculture (USDA) were the primary data sources. A description of individual variables is shown in Table 1 . The selection of variables was made according to Novotný (2012). 
Table 1: Description of variables

\begin{tabular}{|c|c|c|}
\hline $\begin{array}{l}\text { Variable } \\
\text { designation }\end{array}$ & Description of variable & Source \\
\hline BRENT & Price of crude oil (dollars per barrel) & EIA \\
\hline NEER & Nominal Effective Exchange Rate, Trade Partners by Consumer Price Index & IMF \\
\hline IPP & Industrial Production Index in OECD Countries & OECD \\
\hline$R(U S D)$ & 3-month treasury bill: secondary market rate (percent) & FRED \\
\hline OIL & US ending stocks excluding SPR of crude oil (thousand barrels) & EIA \\
\hline RAF & US percent utilization of refinery operable capacity & EIA \\
\hline FARM & $\begin{array}{l}\text { Producer Price Index by commodity for farm products and processed foods } \\
\text { and feeds }\end{array}$ & FRED \\
\hline METAL & Producer Price Index by commodity for metal and metal products & FRED \\
\hline JGP & $\begin{array}{l}\text { Producer Price Index by commodity for miscellaneous products: jewellery, } \\
\text { gold and platinum }\end{array}$ & FRED \\
\hline ETH & Price of ethanol (dollars per gallon) & USDA \\
\hline
\end{tabular}

Source: EIA, FRED, IMF, OECD (2018)

The Vector Error Correction Model was used for this purpose to determine both longterm and short-term causal relationships. To create the resulting model, the econometric methodology was used, namely unit root tests, Granger causality for the determination of statistically significant relationships, information criteria, the Johansen cointegration test and impulse-response analysis (Johansen, 1988). The methods of cointegration analysis are described in Hendy and Juselius (2000; 2001).

\subsection{VAR/VECM model}

The Vector Autoregressive Model (VAR) and the Vector Error Correction Model (VECM) make it possible to express and analyse a simultaneous relation between variables. Arlt (1999) and Juselius (2006) state that VAR analysis is based on the idea that all the variables used to analyse a selected dependency are random and simultaneously dependent. This means that the model structure contains only endogenous variables (except the deterministic components of the model), with their maximum delay time being the same (Stock and Watson, 2001).

The $\operatorname{VAR}(p)$ model can be written in the following form (1), assuming that $C_{\mathrm{s}}=0$ for $s>p$ : 


$$
Y_{t}=\boldsymbol{\eta}+\sum_{s=1}^{p} C_{s} Y_{t-s}+\boldsymbol{U}_{t}
$$

where:

$\boldsymbol{\eta}$ is a vector of constants,

$Y_{t} \quad$ is the $k$ of model variables,

$\boldsymbol{U}_{\boldsymbol{t}}$ is a vector of random model components,

$C_{s}$ is a parameter matrix of endogenous variables in the VAR space, delayed by $s$ periods.

By including a long-term relation in (1), the VECM is obtained in the following form:

$$
\Delta Y_{t}=\boldsymbol{\eta}+\Pi Y_{t-1}+\sum_{s=1}^{p} C_{s} \Delta Y_{t-s}+\boldsymbol{U}_{t}
$$

where:

$\boldsymbol{\eta}$ is a vector of constants,

$Y_{t-1}$ is the $k$ of model variables,

$\Delta Y_{t}$ is the first difference $k$ of model variables,

$\boldsymbol{U}_{\boldsymbol{t}}$ is a vector of random model components,

$\boldsymbol{\Pi}$ is a matrix of long-term relation; $\boldsymbol{\Pi}=\boldsymbol{\alpha} \boldsymbol{\beta}^{\mathrm{T}}$, where $\alpha$ is estimated parameters that express the rate of system adaptation and $\boldsymbol{\beta}$ is a cointegrating vector or a matrix of cointegrating vectors,

$C_{s}$ is a parameter matrix of endogenous variables in the VAR space, delayed by $s$ periods.

Most time series in macroeconomics and finance are non-stationary or integrated with the order I(1), as stated in Engle and Granger (1987) or Enders (2014). I(1) denotes a time series the first differences of which are stationary. That is why data stationarity testing or unit root tests are performed. The Augmented Dickey-Fuller test (ADF) is often used in the literature. The ADF test allows us to test the presence of a unit root based on three models A, B, C. Model A represents a random walk model, Model B contains a constant $(\mu)$, and Model $\mathrm{C}$ contains a constant $(\mu)$ and a trend component $(t)$. The test models are defined as follows:

Model A: $\Delta y_{t}=\gamma y_{t-1}+\sum_{i=1}^{K} \rho_{i} \Delta y_{t-1}+\varepsilon_{t}$,

Model B: $\Delta y_{t}=\mu+\gamma y_{t-1}+\sum_{i=1}^{K} \rho_{i} \Delta y_{t-1}+\varepsilon_{t .}$,

Model C: $\Delta y_{t}=\mu+\beta t+\gamma y_{t-1}+\sum_{i=1}^{K} \rho_{i} \Delta y_{t-1}+\varepsilon_{t}$. 
The determination of the order of integration of the individual time series is based on the null hypothesis: $H_{0}: \gamma=0$, which states that a time series contains a unit root, i.e., that the non-systematic component of time series is of the type I(1). An alternative hypothesis is placed against the null hypothesis: $H_{1}: \gamma<0$, which states that a time series is stationary.

\subsection{Cointegration analysis}

The cointegration analysis is based on the search for non-zero values, the so-called eigenvalues, of the matrix of long-term relations (II). Based on this testing, the number of cointegrating vectors in the VECM model is determined. The matrix of long-term relations $(\boldsymbol{\Pi})$ is equal to the number of its non-zero eigenvalues. This approach uses two test criteria: eigenvalue statistics and trace statistics.

$$
\begin{aligned}
& \lambda_{M A X}(r+1)=-\operatorname{Tln}\left(1-\lambda_{r+1}\right) . \\
& \lambda_{\text {TRACE }}(r)=-T \sum_{i=r+1}^{N} \ln \left(1-\lambda_{i}\right) .
\end{aligned}
$$

The first criterion (eigenvalue statistics) tests the validity of the null hypothesis with the existence of exactly $r$ cointegration vectors versus an alternative hypothesis expressing the occurrence of $r+1$ cointegration vectors. The second test criterion (trace statistics) verifies the validity of the null hypothesis with the existence of maximum $r$ cointegration vectors versus an alternative hypothesis that there are more than $r$ vectors. The results of the second test criterion are shown in Table 5. These methods are also used by Stoklasová (2018a).

\subsection{Impulse-response analysis}

Impulse-response analysis allows analysis of both the short-term and long-term relations between the analysed variables based on the derived model. Arlt (1999) states that the impulse-response analysis is related to the question of what reaction in one time series will be caused by an impulse in another time series within a system that contains multiple time series. This is the study of the relation between two one-dimensional time series in a multidimensional system.

The EViews software in the Impulse table provides six options for transforming the impulses. A Cholesky d.f. adjusted was chosen for transformation in this article. Cholesky uses the inverse of the Cholesky factor of the residual covariance matrix to orthogonalize the impulses. This option imposes an ordering of the variables in the VAR and attributes all of the effect of any common component to the variable that comes first in the VAR system. 
The d.f. adjustment option makes a degrees-of-freedom correction of a small sample when estimating the residual covariance matrix used to derive the Cholesky factor. The $(i, j)$-th element of the residual covariance matrix with the degrees-of-freedom correction is computed as

$$
\sum_{t} \frac{e_{i, t} e_{j, t}}{T-p}
$$

where $p$ is the number of parameters per equation in the VAR.

\section{Econometric Model}

\subsection{Intensity analysis of variables}

The development of the Brent crude oil price and the US dollar is shown in Figure 1. The average Brent oil price was 51.25 USD per barrel, the minimum value was 11.31 USD per barrel (December 1998), and the maximum value was 134.02 USD per barrel (June 2008). Index NEER USD: average $=108.57 ; \min =92.21$ (April 1995), $\max =129.24$ (January 2002).

Figure 1: The development of the Brent Oil Price (USD/barrel) and the US Dollar (index)

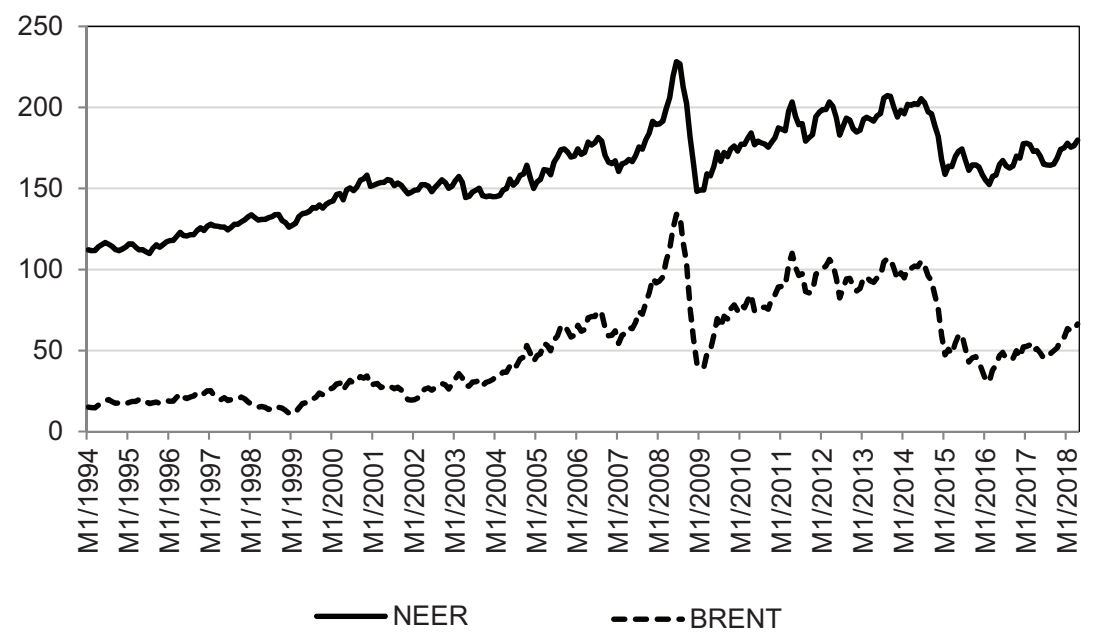

Source: EIA (2018), IMF (2018), own calculations

Since both time series are non-stationary, we examine the interdependence between their monthly logarithmic yields. The time series of monthly logarithmic yields are stationary. The monthly logarithmic yields are given by: 


$$
v_{t}=\ln \left(\frac{y_{t}}{y_{t-1}}\right) \text {, }
$$

where $y_{t}$ is the average monthly value of the variable in time $t$.

The values of the correlation coefficient between the monthly yields of the US dollar nominal effective exchange rate (V_NEER) and the monthly yields of the commodities (V_BRENT, V_FARM, V_METAL, V_JGP, V_ETH) are shown in Table 2.

Table 2: Values of the correlation coefficient

\begin{tabular}{l|c|c|c|c|c}
\hline & $\begin{array}{c}\text { V_NEER x } \\
\text { V_BRENT }\end{array}$ & $\begin{array}{c}\text { V_NEER x } \\
\text { V_FARM }\end{array}$ & $\begin{array}{c}\text { V_NEER x } \\
\text { V_METAL }\end{array}$ & $\begin{array}{c}\text { V_NEER x } \\
\text { V_JGP }\end{array}$ & $\begin{array}{c}\text { V_NEER x } \\
\text { V_ETH }\end{array}$ \\
\hline $\mathbf{1 9 9 4 - 2 0 1 8}$ & -0.32 & -0.17 & -0.39 & -0.16 & -0.28 \\
\hline $\mathbf{2 0 0 4 - 2 0 1 8}$ & -0.47 & -0.24 & -0.48 & -0.18 & -0.35 \\
\hline $\mathbf{2 0 1 4 - 2 0 1 8}$ & -0.51 & -0.36 & -0.57 & -0.15 & -0.49 \\
\hline
\end{tabular}

Source: own calculations

The correlation coefficients are negative in all the cases (weakening of the US dollar was associated with higher commodity prices and vice versa), with the intensity of the recent relationship growing in the oil (BRENT), industrial metals (METAL), agricultural commodities (FARM) and ethanol (ETH). The intensity of the relationship dropped only in the case of jewellery, gold and platinum (JGP) in 2014-2018. In line with the assumptions, it appears that investors look for an alternative valuation of their investments on commodity markets in an environment of low real interest rates.

\subsection{VAR/VECM model}

The preparatory phase of estimating the VAR model is testing the stationarity of variables included in the model or their first differences. Sims et al. (1990) show some interesting information about the inference in linear time series with some unit roots. All of these variables were seasonally adjusted in addition to a logarithmic transformation.

The test results for all the variables are provided in Table 3. The Dickey-Fuller test (ADF) was used to test the stationarity. The second column contains the T-statistics; the following column contains the corresponding levels of statistical significance. The last column includes the testing results: $\mathrm{N}=$ non-stationary $\left(H_{0}\right.$ not rejected $), \mathrm{S}=$ stationary ( $H_{0}$ rejected). 
These variables for the VAR model exhibit the properties of first-order nonstationarity, i.e., I(1); therefore, long-run cointegration relationships may exist between these variables.

Table 3: Testing unit root of variables in levels and their first differences

\begin{tabular}{|c|c|c|c|c|c|c|c|}
\hline Variable & T-stat & Sign. & Result & Variable & T-stat & Sign. & Result \\
\hline LN_BRENT & -1.84 & 0.359 & $\mathrm{~N}$ & $d\left(L N \_B R E N T\right)$ & -12.98 & 0.000 & S \\
\hline LN_NEER & -1.96 & 0.305 & $\mathrm{~N}$ & $d\left(L N \_N E E R\right)$ & -11.46 & 0.000 & S \\
\hline$L N \_I P P$ & -1.77 & 0.397 & $\mathrm{~N}$ & $d\left(L N \_I P P\right)$ & -5.38 & 0.000 & S \\
\hline$L N \_R(U S D)$ & -1.26 & 0.649 & $\mathrm{~N}$ & $d\left(L N \_R(U S D)\right)$ & -14.48 & 0.000 & $\mathrm{~S}$ \\
\hline LN_OIL & -1.66 & 0.451 & $\mathrm{~N}$ & $d\left(L N \_O I L\right)$ & -14.23 & 0.000 & S \\
\hline$L N \_R A F$ & -1.57 & 0.496 & $\mathrm{~N}$ & $d\left(L N \_R A F\right)$ & -6.24 & 0.000 & S \\
\hline LN_ETH & -1.82 & 0.371 & $\mathrm{~N}$ & $d\left(L N \_E T H\right)$ & -5.91 & 0.000 & s \\
\hline
\end{tabular}

Source: own calculations

The next step is the estimation of the $\operatorname{VAR}(p)$ model. The model estimation includes a determination of $p$ order for delayed variables ( $L N \_B R E N T, L N \_N E E R, L N \_I P P$, $\left.L N \_R(U S D), L N \_O I L, L N \_R A F, L N \_E T H\right)$ in a vector autoregressive model. This delay level is usually the same for all VAR model equations. The VAR(1) model was chosen for further considerations (Schwarz, 1978).

The number of cointegration relationships in the VAR(1) model is calculated using the Johansen's method, as shown in Johansen (1995). Table 4 shows results for all the models. Model 3 was selected based on the Akaike information criterion and the Schwarz criterion, where the lowest value indicates the best model. This is a model that includes a limited level constant and does not include a trend component.

Table 4: Johansen cointegration test summary

\begin{tabular}{l|c|c|c|c|c}
\hline $\begin{array}{l}\text { Data trend } \\
\text { Test type }\end{array}$ & $\begin{array}{c}\text { None } \\
\text { No intercept } \\
\text { No trend }\end{array}$ & $\begin{array}{c}\text { None } \\
\text { Intercept } \\
\text { No trend }\end{array}$ & $\begin{array}{c}\text { Linear } \\
\text { Intercept } \\
\text { No trend }\end{array}$ & $\begin{array}{c}\text { Linear } \\
\text { Intercept } \\
\text { Trend }\end{array}$ & $\begin{array}{c}\text { Quadratic } \\
\text { Intercept } \\
\text { Trend }\end{array}$ \\
\hline Akaike criterion & -23.907 & -24.051 & -24.053 & -24.051 & -24.027 \\
\hline Schwarz criterion & -23.299 & -23.431 & -23.471 & -23.355 & -23.268 \\
\hline
\end{tabular}

Source: own calculations 
Table 5: Cointegration analysis

\begin{tabular}{l|c|c|c|c}
\hline Hypothesized no. of CE(s) & Eigenvalue & Trace statistic & Critical value & Sign. \\
\hline None * & 0.2372 & 170.7681 & 125.6154 & 0.0000 \\
\hline At most 1 & 0.1234 & 92.2598 & 95.7537 & 0.0849 \\
\hline At most 2 & 0.0787 & 54.0701 & 69.8189 & 0.4585 \\
\hline
\end{tabular}

Note: * denotes rejection of the hypothesis at the 0.05 level

Source: own calculations

The test in Table 5 confirms the existence of one cointegration relationship for the VECM(1). The estimation led to a cointegration Equation 10.

$$
\begin{aligned}
& L N_{-} B R E N T=0.53 L N_{-} E T H+2.94 L N_{-} I P P-0.81 L N_{-} N E E R-0.36 L N_{-} O I L- \\
& -0.01 L N_{-} R(U S D)-7.88 L N_{-} R A F+33.95 .
\end{aligned}
$$

The cointegration equation shows that the Brent crude oil price is positively affected in the long term by industrial production in OECD countries. Growth in this variable causes an increase in the oil price. The equation also shows that there is a negative relationship between the Brent crude oil price and the effective exchange rate of the dollar. This means that the increase in the effective exchange rate of the dollar causes a reduction in the Brent crude oil price in the long run, which is in contradiction with the assumption.

\begin{tabular}{|c|c|c|c|c|}
\hline & Coefficient & Std. error & $t$-ratio & Sign. \\
\hline$d\left(L N \_I P P(-1)\right)$ & 1.546 & 0.758 & 2.040 & $0.04109^{* *}$ \\
\hline$d\left(L N \_R(U S D)(-1)\right)$ & 0.019 & 0.015 & 1.266 & 0.20830 \\
\hline$d\left(L N \_O I L(-1)\right)$ & -0.368 & 0.157 & -2.344 & $0.01355^{* *}$ \\
\hline$d\left(L N \_R A F(-1)\right)$ & 0.067 & 0.163 & 0.411 & 0.60124 \\
\hline$d\left(L N \_N E E R(-1)\right)$ & -0.814 & 0.374 & -2.176 & $0.03147^{* *}$ \\
\hline$d\left(L N \_E T H(-1)\right)$ & -0.075 & 0.053 & -1.415 & 0.13879 \\
\hline$d\left(L N \_B R E N T(-1)\right)$ & 0.204 & 0.063 & 3.238 & $0.00217^{* * *}$ \\
\hline EC1 & -0.049 & 0.017 & -2.882 & $0.00866^{* * *}$ \\
\hline CONST & 0.003 & 0.004 & 0.750 & 0.40230 \\
\hline
\end{tabular}

Table 6: VECM estimates: $d($ LN_BRENT)

Note: Statistical significance at the 0.01 level $\left({ }^{* *}\right)$, at the 0.05 level $\left({ }^{* *}\right)$, at the 0.1 level $\left({ }^{*}\right)$

Source: own calculations 
There is also a negative relationship between the Brent crude oil price and the real interest rate, the effects of oil inventories and the rate of use of refineries in the USA. Growth in real interest rate causes the Brent crude oil price to decline, confirming that investors seek investment returns on commodity markets if the return on financial assets is low. Growth in the oil inventories and growth in the use of refineries results in a decrease in the price of oil.

The VECM is a tool for examining short-term deviations needed to achieve a longterm equilibrium between two variables. The VECM estimation for the cointegration relationship is found in Table 6.

$$
\begin{aligned}
& d\left(L N \_B R E N T\right)= \\
& -0.049 *\left\{L N \_B R E N T(-1)-0.53 * L N \_E T H(-1)-2.94 * L N \_I P P(-1)+0.81 *\right. \\
& * L N \_N E E R(-1)++0.36 * L N \_O I L(-1)+0.01 * L N \_R(U S D)(-1)+7.88 * \\
& \left.* L N \_R A F(-1)-33.95\right\}+0.204 * d\left(L N \_B R E N T(-1)\right)-0.075 * d\left(L N \_E T H(-1)\right)+ \\
& +1.546 * d\left(L N \_I P P(-1)\right)-0.814 * d\left(L N \_N E E R(-1)\right)-0.368 * d\left(L N \_O I L(-1)\right)+ \\
& +0.019 * d\left(L N \_R(U S D)(-1)\right)+0.067 * d\left(L N \_R A F(-1)\right)+0.003 .
\end{aligned}
$$

Causality is captured by the statistically significant value EC1 (-0.049), which indicates that this variable will be modified by $4.9 \%$ within 1 month in the case of a longterm instability of the oil price level. In other words, complete elimination of instability would last approximately 20.5 months (1/0.049).

A statistically significant positive relationship between the Brent crude oil price and the industrial production in OECD countries is delayed by one month. A statistically negative relationship exists between the Brent crude oil price and the effective exchange rate of the dollar with a one-month delay, and the same result applies to the effects of oil inventories. A statistically significant relationship between the Brent crude oil price and the real interest rate, or the rate of use of refineries in the USA respectively, has not been demonstrated.

Table 7: Model assumptions

\begin{tabular}{l|l|l|l}
\hline & \multicolumn{1}{|c|}{ Autocorrelation } & Heteroskedasticity & \multicolumn{1}{c}{ Normality } \\
\hline Null hypothesis & $\begin{array}{l}\text { H0: absence } \\
\text { of autocorrelation }\end{array}$ & $\begin{array}{l}\text { H0: absence } \\
\text { of heteroskedasticity }\end{array}$ & $\begin{array}{l}\text { H0: normality } \\
\text { of residues }\end{array}$ \\
\hline Test & Ljung-Box & ARCH - LM & Doornik - Hansen \\
\hline Significance & 0.187 & 0.081 & 0.097 \\
\hline
\end{tabular}

Source: own calculations 
Table 7 shows the testing results for the model assumptions. The Doornik-Hansen test does not reject the null hypothesis of normality of residues. The Ljung-Box test does not reject the null hypothesis of absence of autocorrelation. The ARCH-LM test does not reject the null hypothesis of absence of heteroskedasticity. The tests were performed at the significance level of 0.05 .

\subsection{Granger causality}

This chapter deals with the testing of short-term relationships (Granger causality). We test whether one series acts on the other in Granger's sense for the time series pairs. If the X series acts on the Y series in Granger's sense, then the X-series values provide statistically significant information about the future Y-series values. Therefore, it is a tool that evaluates the ability of one series to predict the future values of the other. We test the hypothesis that the series in question does not act in Granger's sense against an alternative hypothesis that denies the hypothesis being tested. Due to the fact that these are monthly data, Granger causality is tested at the 1,2, ., 12 delay. We consider the 5\% significance level. The results of the series 1 delay test are shown in Table 8 .

Table 8: Pairwise Granger causality tests (lag 1)

\begin{tabular}{l|c|c}
\hline Null Hypothesis: & Statistic & Sign. \\
\hline$d\left(L N \_N E E R\right)$ does not Granger-cause $d\left(L N \_B R E N T\right)$ & 5.62 & $\mathbf{0 . 0 1 7}$ \\
$d\left(L N \_B R E N T\right)$ does not Granger-cause $d\left(L N \_N E E R\right)$ & 4.74 & $\mathbf{0 . 0 2 9}$ \\
\hline$d\left(L N \_N E E R\right)$ does not Granger-cause $d\left(L N \_I P P\right)$ & 0.43 & 0.509 \\
$d\left(L N \_I P P\right)$ does not Granger-cause $d\left(L N \_N E E R\right)$ & 8.35 & $\mathbf{0 . 0 0 4}$ \\
\hline$d\left(L N \_N E E R\right)$ does not Granger-cause $d\left(L N \_O I L\right)$ & 0.11 & 0.746 \\
$d\left(L N \_O I L\right)$ does not Granger-cause $d\left(L N \_N E E R\right)$ & 5.08 & $\mathbf{0 . 0 2 4}$ \\
\hline$d\left(L N \_N E E R\right)$ does not Granger-cause $d\left(L N \_R A F\right)$ & 4.61 & $\mathbf{0 . 0 3 2}$ \\
$d\left(L N \_R A F\right)$ does not Granger-cause $d\left(L N \_N E E R\right)$ & 0.12 & 0.734 \\
\hline$d\left(L N \_N E E R\right)$ does not Granger-cause $d\left(L N \_E T H\right)$ & 0.29 & 0.586 \\
$d\left(L N \_E T H\right)$ does not Granger-cause $d\left(L N \_N E E R\right)$ & 2.16 & 0.142 \\
\hline$d\left(L N \_N E E R\right)$ does not Granger-cause $d\left(L N \_R(U S D)\right)$ & 0.76 & 0.385 \\
$d\left(L N \_R(U S D)\right)$ does not Granger-cause $d\left(L N \_N E E R\right)$ & 2.52 & 0.112 \\
\hline
\end{tabular}

Source: own calculations 
Changes in NEER Granger cause changes in BRENT and RAF with a one-month delay. Changes in BRENT Granger cause changes in NEER with a one-month delay.

The time series of the nominal effective exchange rate (NEER) affects the crude oil price index (BRENT) and the US percent utilization of refinery operable capacity (RAF) in Granger's sense. Changes in IPP and OIL cause changes in NEER. Short-term relationships between these variables were confirmed. A short-term relationship between the crude oil price index (NEER) and (ETH) and (R(USD)) was not identified and the series are not related.

\subsection{Impulse-response analysis}

The impulse-response function of $L N \_B R E N T$ (Brent crude oil price) on a unit shock of $L N \_I P P$ (industrial production in OECD countries) shows an increase in the variable $L N \_B R E N T$ not opposed by any immediate process (Figure 2). The impulse-response function of $L N \_B R E N T$ on a unit shock of $L N \_R(U S D)$ (real interest rate) shows the same result. The reactions of $L N \_B R E N T$ on a unit shock of $L N \_N E E R$ (effective dollar exchange rate), $L N \_O I L$ (effects of oil inventories), and $L N \_R A F$ (rate of use of US refineries) are negative. The system returns to equilibrium for more than 12 months. On the horizontal axis there is a delay in the month, on the vertical axis there is a response. 
Figure 2: Impulse-response function (response to Cholesky one S.D. innovations)

Response of LN_BRENT to LN_BRENT

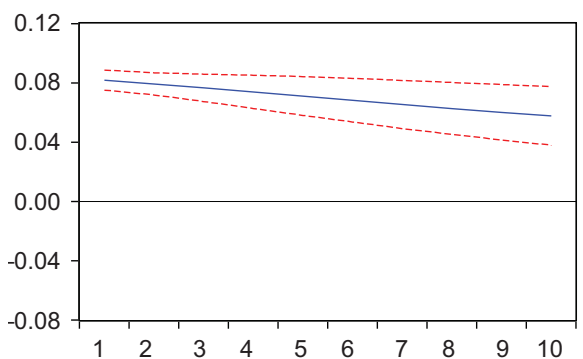

Response of LN_BRENT to LN_IPP

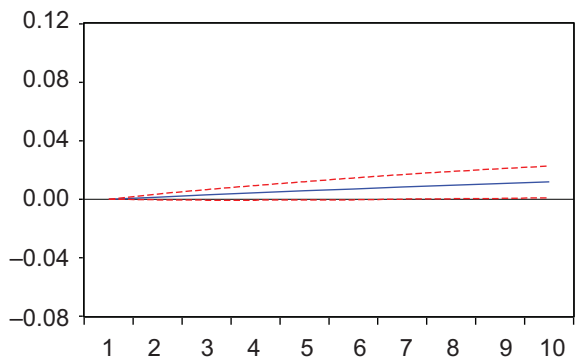

Response of LN_BRENT to LN_OIL_USA

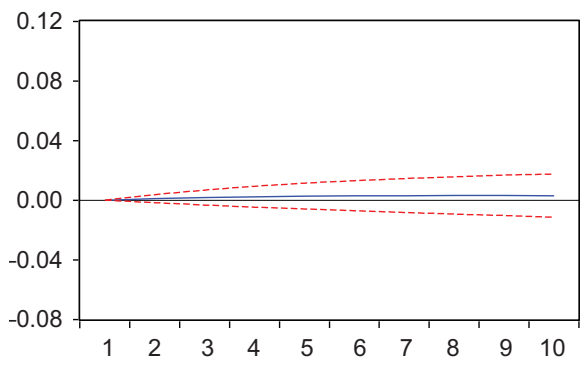

Response of LN_BRENT to LN_ETH

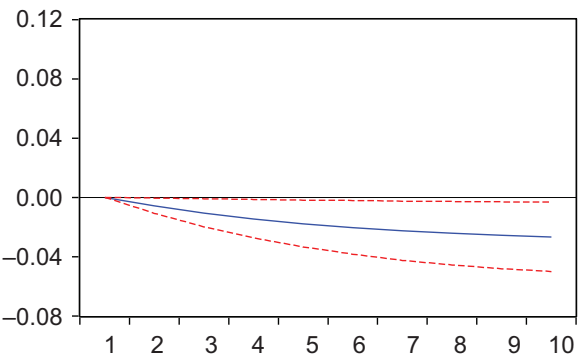

Response of LN_BRENT to LN_NEER

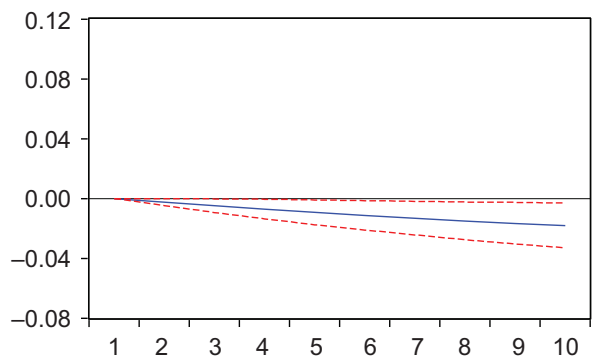

Response of LN_BRENT to LN_R_USD

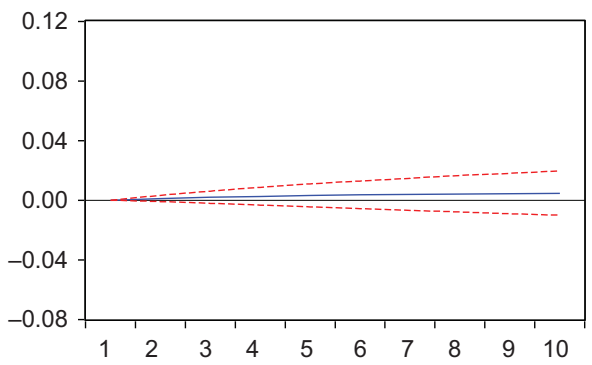

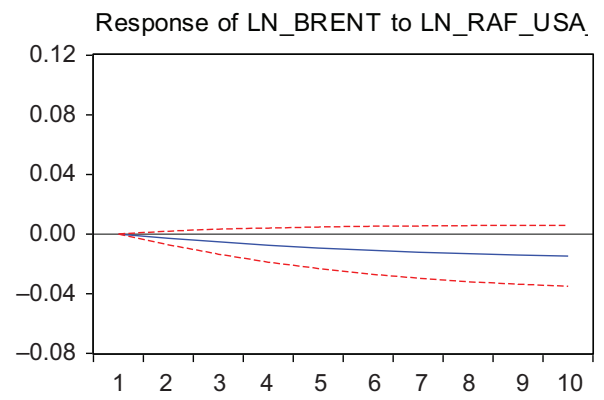

Source: own calculations 


\section{Conclusions}

There has traditionally been a negative correlation between the US dollar exchange rate and the oil price, although the relationship between these two variables changed considerably in the past, as reported by Cuaresma and Breitenfellner (2008). There are several explanations for the inverse relationship between the oil price and the US dollar exchange rate. One explanation is the growing role of investors on commodity markets, connected with declining financial asset yields in developed countries. The weakening of the US dollar against the currencies of countries with floating exchange rates also means that the price of oil expressed in local currency decreases, which may affect the growth of oil demand in these countries, as reported by Cuaresma and Breitenfellner (2008).

This article analyses the development of the intensity and direction of dependence between the effective US dollar exchange rate and the Brent oil price and other commodities in the period from 1994 to 2018. The correlation coefficients take negative values in all the cases, that is, weakening of the US dollar exchange rate is associated with higher commodity prices and vice versa. The value of the correlation coefficient between the nominal effective exchange rate of the US dollar and the Brent price was -0.51 in the period from 2014 to 2018 .

The last part of the article dealt with the question whether there is a long-term relationship between the variables (Brent crude oil price (BRENT), effective dollar exchange rate (NEER), industrial production in OECD countries (IPP), real interest rate (R(USD), rate of use of US refineries (RAF) and effects of oil inventories (OIL)). Johansen's test confirms the existence of one long-term relationship. The value of the adjustment coefficient $(-0.049)$ in the Table 5 indicates that more than $4.9 \%$ of the short-term deviations from the long-term equilibrium are corrected already in the following month. In other words, removing the complete imbalance would take approximately two years (1/0.049 $=20.5$ months). Regarding regression coefficients, it can be argued that the Brent crude oil price is positively related to industrial production in OECD countries, with a monthly delay, i.e., a drop in the industrial production in OECD countries is followed by a decrease in the Brent crude oil price after one month. A statistically negative relationship exists between the Brent crude oil price and the effective exchange rate of the dollar with a onemonth delay. This is in line with the assumption that a negative relationship exists between the variables. A statistically significant relationship between the Brent crude oil price and the real interest rate, or the rate of use of refineries in the USA respectively, has not been demonstrated.

The residual component is not correlated; residual component heteroskedasticity and residual component non-normality were not demonstrated. 
The next section tested the hypothesis that there is a short-term relationship between the effective exchange rate of the US dollar and the oil price. Changes in BRENT, IPP and OIL Granger cause changes in NEER with a one-month delay. Changes in NEER Granger cause changes in BRENT and RAF with a one-month delay. The same results were computed for 2, 3, 4 and 6-month delays. Short-term relationships between these variables were confirmed.

Oil is traded in US dollars. If there is a depreciation in the US dollar, oil-producing companies proceed to reduce oil production, and the resulting low oil supply has a positive effect on its price. Other crucial factors affecting the price of oil are stock and commodity markets. The development of the commodity market is similar to that of the stock market. If the stock market does not prosper, investors resort to investments in less risky assets, such as oil commodities.

According to Sputnik (2018), specialists believe that the US should be alert because Iran has shifted to the euro as part of its oil business. Many oil exporters and importers are also dissatisfied with US currency dependency. The world is inclined to a so-called de-dollarization of the world energy market.

\section{References}

Aloui, R., Ben Aissa, M. S., Ngueven, D. K. (2013). Conditional Dependence Structure between Oil Prices and Exchange Rates: A Copula-GARCH Approach. Journal of International Money and Finance, 32, 719-738, https://doi.org/10.1016/j.jimonfin.2012.06.006

Amano, R. A., van Norden, S. (1998). Exchange Rates and Oil Prices. Review of International Economics, 6(4), 683-694, https://doi.org/10.1111/1467-9396.00136

Arlt, J. (1999). Moderní metody modelování ekonomických časových řad. Praha: Grada Publishing. ISBN 80-7169-539-4.

Basher, S. A., Haug, A. A., Sadorsky, P. (2012). Oil Prices, Exchange Rates and Emerging Stock Markets. Energy Economics, 34(1), 227-240, https://doi.org/10.1016/j.eneco.2011.10.005

Beckmann, J., Czudaj, R. (2013). Oil Prices and Effective Dollar Exchange Rates. International Review of Economics \& Finance, 27, 621-636, https://doi.org/10.1016/j.iref.2012.12.002

Bénassy-Quéré, A., Mignon, V., Penot, A. (2005) China and the Relationship between the Oil Price and the Dollar. CEPII. Working Paper No. 2005-16.

Berument, M. H., Sahin, A., Sahin, S. (2014). The Relative Effects of Crude Oil Price and Exchange Rate on Petroleum Product Prices: Evidence from a set of Northern Mediterranean Countries. Economic Modelling, 42, 243-249,https://doi.org/10.1016/j. econmod.2014.07.019

Brown, S. P. A., Virmani, R., Alm, R. (2008). Crude Awakening: Behind the Surge in Oil Prices. Economic Letter - Federal Reserve Bank of Dallas, 3(5). 
Chang, H. F., Huang, L. C., Chin, M. C. (2013). Interactive Relationships between Crude Oil Prices, Gold Prices, and the NT-US Dollar Exchange Rate - A Taiwan Study. Energy Policy, 63, 441-448, https://doi.org/10.1016/j.enpol.2013.09.029

Chaudhuri, K., Daniel, B. C. (1998). Long-Run Equilibrium Real Exchange Rates and Oil Prices. Economics Letters, 58(2), 231-238, https://doi.org/10.1016/S0165-1765(97)00282-6

Chen, H., Liu, L., Wang, Y., Zhu, Y. (2016). Oil Price Shocks and U.S. Dollar Exchange Rates. Energy, 112, 1036-1048, https://doi.org/10.1016/j.energy.2016.07.012

CNB (2011). Souvislost mezi vývojem ceny ropy Brent a měnového kurzu amerického dolaru. [Retrieved 2018-06-20] Available at: https://www.cnb.cz/cs/menova_politika/ zpravy_o_inflaci/2011/2011_II/box_a_prilohy/zoi_Il_2011_box_Il.html

Cuaresma, J. C., Breitenfellner, A. (2008).Crude Oil Prices and the USD/EUR Exchange. Monetary Policy \& the Economy, 4, 102-121.

EIA (2018). Energy Information Administration. [Retrieved 2018-06-30] Available at: http://www.eia.gov/dnav/pet/hist/LeafHandler.ashx?n=pet\&s=rclc1\&f=m

Enders, W. (2014). Applied Econometric Time Series. Hoboken: Wiley. ISBN 978-1-118-80856-6.

Engle, R. F., Granger, C., W. J. (1987). Co-Integration and Error Correction: Representation, Estimation, and Testing. Econometrica, 55(2), 251-276, https://doi.org/10.2307/1913236

Filip, O., Janda, K., Kristoufek, L., Zilberman, D. (2016). Dynamics and Evolution of the Role of Biofuels in Global Commodity and Financial Markets. Nature Energy, 1(12), 161-169, https://doi.org/10.1038/NENERGY.2016.169

FRED (2018). The Federal Reserve Bank of St. Louis. [Retrieved 2018-06-30] Available at: https://fred.stlouisfed.org/series/WPU10

Habib, M. M., Kalamova, M. (2007). Are There Oil Currencies? The Real Exchange Rate of Oil Exporting Countries. European Central Bank. Working Paper Series No. 839.

Hendry, D., Juselius, K. (2000). Explaining Cointegration Analysis: Part I. The Energy Journal, 21(1), 1-42, https://doi.org/10.5547/issn0195-6574-ej-vol21-no1-1

Hendry, D., Juselius, K. (2001). Explaining Cointegration Analysis: Part II. The Energy Journal, 22(1), 75-120, https://doi.org/10.5547/issn0195-6574-ej-vol22-no1-4

Hošek, J., Komárek, L., Motl, M. (2011). Měnová politika a cena ropy. Politická ekonomie, 59(1), 22-46, https://doi.org/10.18267/j.polek.770

IMF (2018). International Monetary Fund. [Retrieved 2018-06-30] Available at: http://data.imf.org/regular.aspx?key=61545850

Jawadi, F., Louhichi, W., Ameur, H. B., Cheffou, A. I. (2016). On Oil-US Exchange Rate Volatility Relationships. An Intraday Analysis Economic Modelling, 59, 329-334, https://doi.org/10.1016/j.econmod.2016.07.014

Johansen, S. (1988). Statistical Analysis of Cointegrating Vectors. Journal of Economic Dynamics and Control, 12(2-3), 231-254, https://doi.org/10.1016/0165-1889(88)90041-3 Johansen, S. (1995). Likelihood-Based Inference in Cointegrated Vector Autoregressive Models. Oxford: Oxford University Press. ISBN-13: 9780198774501. 
Juselius, K. (2006). The Cointegrated VAR Model - Methodology and Applications. Oxford: Oxford University Press. ISBN 0-19-928567-5.

Kiran, B. (2011). Fractional Cointegration Relationship between Oil Prices and Stock Markets: An Empirical Analysis from G7 Countries. Prague Economic Papers, 20(2), 177-189, https://doi.org/10.18267/j.pep.395

Kristoufek, L., Janda, K., Zilberman, D. (2014). Price Transmission between Biofuels, Fuels, and Food Commodities. Biofuels, Bioproducts and Biorefining, 8(3), 362-373, https://doi.org/10.1002/bbb.1464

Kristoufek, L., Janda, K., Zilberman, D. (2016). Comovements of Ethanol-related Prices: Evidence from Brazil and the USA. GCB Bioenergy, 8(2), 346-356, https://doi.org/10.1111/ gcbb. 12260

Muñoz, M. P., Dickey, D. A. (2009). Are Electricity Prices Affected by the US Dollar to Euro Exchange Rate? The Spanish Case. Energy Economics, 31(6), 857-866, https://doi.org/10.1016/j.eneco.2009.05.011

Novotný, F. (2012). The Link Between the Brent Crude Oil Price and the US Dollar Exchange Rate. Prague Economic Papers, 21(2), 220-232, https://doi.org/10.18267/j.pep.420

OECD (2018). Organisation for Economic Co-operation and Development. [Retrieved 2018-0630] Available at: http://stats-3.oecd.org/index/aspx?DatasedCode=MEI_REAL

Schulmeister, S. (2009). Trading Practices and Price Dynamics in Commodity Markets and the Stabilizing Effects of a Transaction Tax. WIFO (Austrian Institute of Economic Research).

Schwarz, G. (1978). Estimating the Dimension of a Model. The Annals of Statistics, 6(2), 461-464, https://doi.org/10.1214/aos/1176344136.

Serra, T., Zilberman, D., Gil, J. M., Goodwin, B. K. (2011). Nonlinearities in the U.S. Cornethanol-oil-gasoline Price System. Agricultural Economics, 42(1), 35-45, https://doi.org/10.1111/j.1574-0862.2010.00464.x

Serra, T., Zilberman, D. (2013). Biofuel-related price transmission literature: A review. Energy Economics, 37(C), 141-151, https://doi.org/10.1016/j.eneco.2013.02.014

Sims, C. A., Stock, J. H., Watson, M. W. (1990). Inference in Linear Time Series Models with Some Unit Roots. Econometrica, 58(1), 113-44, http://doi.org/10.2307/2938337

Sputnik ČR (2018). Vývozci ropy se zbavují dolaru, přecházejí na jiné měny. [Retrieved 2018-06-10] Available at: https://cz.sputniknews.com/svet/201804247220361-vyvozci-ropy-se -zbavuji-dolaru-prechazeji-na-jine-meny/

Stock, H. J., Watson, W. M. (2001). Vector Autoregressions. Journal of Economic Perspectives, 15(4), 101-115, http://doi.org/10.1257/jep.15.4.101

Stoklasová, R. (2018a). Default Rate in the Czech Republic Depending on Selected Macroeconomic Indicators. E\&M Economics and Management, 21(2), 69-82, https://doi.org/10.15240/tul/001/2018-2-005 
Stoklasová, R. (2018b). Short-term and Long-term Relationships between Gold Prices and Oil Prices. Scientific Papers of the University of Pardubice, 43(2), 221-231.

USDA (2018). United States Department of Agriculture Economic Research Service. U.S. Bioenergy Statistics. [Retrieved 2018-12-10] Available at: https://www.ers.usda.gov/ data-products/us-bioenergy-statistics/

W4T.CZ (2018). Cena ropy dnes klesá vlivem sílícího amerického dolaru. [Retrieved 2018-06-10] Available at: https://www.w4t.cz/cena-ropy-dnes-klesa-vlivem-siliciho-americkeho -dolaru-75216/

Yang, L., Cai, X. J., Hamori, S. (2018). What Determines the Long-Term Correlation between Oil Prices and Exchange Rates? The North American Journal of Economics and Finance, 44, 40-152, https://doi.org/10.1016/j.najef.2017.12.003 